Vietnam Academy of Science and Technology
Vietnam Journal of Earth Sciences
hAST)

\title{
Geochemistry of late Miocene-Pleistocene basalts in the Phu Quy island area (East Vietnam Sea): Implication for mantle source feature and melt generation
}

\author{
Le Duc Anh ${ }^{1,4^{*}}$, Nguyen Hoang², Renat B. Shakirov³, Tran Thi Huong² \\ ${ }^{1}$ Institute of Marine Geology and Geophysics, VAST, Hanoi, Vietnam \\ ${ }^{2}$ Institute of Geological Sciences, VAST, Hanoi, Vietnam \\ ${ }^{3}$ V.I. Il'ichev Pacific Oceanological Institute (POI), Far Eastern Branch of Russian Academy of Sciences, \\ Vladivostok, Russia \\ ${ }^{4}$ Graduate University of Science and Technology, VAST, Hanoi, Vietnam
}

Received 21April 2016. Accepted 19 July 2017

\begin{abstract}
The chemical compositions of late Miocene - Pleistocene basalts in Phu Quy island defines two major geochemical groups that reflect the formation and development of the island. The early low alkaline, $\mathrm{TiO}_{2}$ and $\mathrm{P}_{2} \mathrm{O}_{5}$, and high $\mathrm{SiO}_{2}$ group, comprising olivine and tholeiitic basalts, forms the base of the island. The later high alkaline, $\mathrm{TiO}_{2}$, and $\mathrm{P}_{2} \mathrm{O}_{5}$, and low $\mathrm{SiO}_{2}$ group, produced by central-type volcanic eruptions consisting of alkaline olivine and olivine basalts, overlies the early eruptive group. Crustal contamination may be expressed by the positive correlation between $\mathrm{Ba} / \mathrm{Nb}$ and $\mathrm{SiO}_{2}$, which are higher in early eruptive basalts, possibly reflecting the involvement of crustal material, either in the source region or interaction of the melt on the way to the surface. However, negative relationship between $\mathrm{Ba}$ and $\mathrm{SiO}_{2}$, and positive correlation between $\mathrm{Nb} / \mathrm{Y}$ and $\mathrm{Zr} / \mathrm{Y}$ observed for two basaltic series may reflect the effect of melting pressures and degrees of partial melting. Methods of calculating the primitive basaltic melts based on the principle of olivine incremental additions to the basalt until the composition is equilibrated with the residual olivine at $\mathrm{Fo}_{89-90}$ may be used. The computed results show that the early basalts were generated under pressures of about $18-20 \mathrm{~Kb}$ (ca. $55-60 \mathrm{~km})$ and the later basalts were formed in the pressure range of 20 to $25 \mathrm{~Kb}$ (corresponding to the depths about 60 to $75 \mathrm{~km}$ ). The close range of melting pressures suggests decompression polybaric melting of a mantle source, which allows for mixing of various melt portions, resulting in the formation of geochemically linear relationship. It has been demonstrated that the post-opening volcanism was unrelated to an important tectonic phase and that the calculated extension factor $(\beta)$ for the regional major extension fault systems is not significant (ca. 1.3) to trigger mantle melting. Therefore, the infiltration of asthenospheric flows resulting from the Neo-Tethys closure following the collision between India and Eurasia in the late Tertiary, may not only raise the mantle temperature leading to the melting but also appear to be the major driving force of marginal sea opening in the western Pacific, including the East Vietnam Sea.
\end{abstract}

Keywords: Intraplate basalt volcanism, Phu Quy island, East Vietnam Sea, Vietnam late Cenozoic volcanism, mantle source.

C2017 Vietnam Academy of Science and Technology

\section{Introduction}

The South-Central coast of Vietnam is a

*Corresponding author, Email: leducanh010282@gmail.com constituent of present Southeast Asian geomorphology. This is a structurally complex region formed as a consequence of the interaction of lithospheric plates at different stages. Normally, tectonic activity, e.g. opening of 
a marginal sea, is usually accompanied by magmatism. The difference in Southeast Asia, however, is that the extension tectonic activity of the East Vietnam Sea during 32-16 Ma period was not accompanied by significant volcanism, instead intensive volcanic eruptions occurred only from about $15 \mathrm{Ma}$, and particularly strong since about 7 Ma (Barr and McDonald., 1981; Kudrass et al., 1986; Ru and Pigott, 1986; Tu et al., 1991, 1992; Chung et al., 1997; Lee at al., 1998; Yan et al., 2006; Li et al., 2015). Studies of the relationship between Cenozoic volcanism and tectonic activity show that the magmatic formations appear mostly at the interaction of tectonic pullapart zones, which facilitates the pathway for the magma to reach the surface (Barr and McDonald, 1981; Rangin et al., 1995). However, new geochemical studies of Cenozoic basalts in Southeast Asia and the continental shelf indicate that the generation of basaltic magma has undergone different stages of formation and development in accordance with certain pressure and temperature conditions of the mantle source (Hoang et al., 1996; Hoang and Flower, 1998; Flower et al., 1992, 1998, 2001). The increase in temperature (and pressure) of the mantle should lead to changes in some of the physio-mechanical properties of the lithosphere mantle, for example, increasing the plasticity, gradually converting it to the asthenosphere, resulting in decompression melting. This effect, on the one hand, causes thinning of the lithosphere mantle while simultaneously uplifting the upper crust and stretching the surface, destroying weak structures in the crust to facilitate lava passage to the surface. The clear illustration for this process is the appearance of Neogene-Quaternary basalt coverings following the uplift of the Central Highlands (Vietnam) (Flower et al., 1993; Rangin et al., 1995; Hoang and Flower, 1998; Carter et al., 2000). Volcanic activities in the East Vietnam Sea basin and the Vietnamese continental shelf were widespread following the cessation of the East Sea opening (Koloskov et al., 1989, 1999, 2003, 2016). These magmatic activities demonstrate that they are not associated with any important tectonic phase in the area (Li et al., 2013; Ding et al., 2016 and citations therein).

The objectives of this study are to use the major and trace element geochemical compositions of basalts of Phu Quy island, in combination with geochemical data of basalts in the nearby areas and field survey data, in order to (1) classify the basalt series based on their geochemical and petrological characteristics, and possibility of crustal contamination of the melt; (2) to clarify the relationship between the distribution characteristics of the basalts and local fault systems; and (3) to calculate the melting pressures of the basalts.

\section{Geomorphological and tectonic charac- teristics of Phu Quy island}

Phu Quy island belongs to the southCentral continental shelf area from $10^{\circ} 29^{\prime}$ to $10^{\circ} 33^{\prime} \mathrm{N}, 108^{\circ} 55^{\prime} 30^{\prime \prime}$ to $108^{\circ} 58^{\prime} 32.5^{\prime \prime} \mathrm{E}$ of $\mathrm{Phu}$ Quy island district, Binh Thuan province. The island covers an area of $16.4 \mathrm{~km}^{2}$, surrounded by islets of Hon Tranh $\left(2.8 \mathrm{~km}^{2}\right)$, Hon Den, Hon Giua, Hon Do and Da Ty. The population is estimated to be 35,218 people in 2015, a density of 2,147 people $/ \mathrm{km}^{2}$, with fishing as the major source of livelihood.

According to the fieldwork data combined with the published literature (Koloskov et al., 1989, 1999, 2016), seven volcanic cones were identified in the Phu Quy island area including submarine volcanoes (Figure 1). The largest volcano is located in the northern part of the island with a height of $90 \mathrm{~m}$, having a crater diameter of about $120 \mathrm{~m}$ and base diameter of about $1300 \mathrm{~m}$. The remaining volcanoes are smaller in size, with crater diameters ranging between 80 and $100 \mathrm{~m}$ and base diameters from about $600 \mathrm{~m}$ to $1000 \mathrm{~m}$. Volcanic activity in the Vietnamese continental shelf is believed to have occurred some 12 million years ago, the latest eruption having been recorded in 1923 forming the Ile des Cendres subma- 
rine volcanic group (Lee et et al., 1998; Koloskov et al., 2009, 2016). The early eruption phase in Phu Quy island occurred about 2.6 Ma forming pyroclastic layers with a total thickness up to $60 \mathrm{~m}$ (Figure 1). The later central cone-type eruptions forming massive lava flows occurred about $1 \mathrm{Ma}$ (Koloskov et al., 2016; Le Duc Anh et al., 2017).

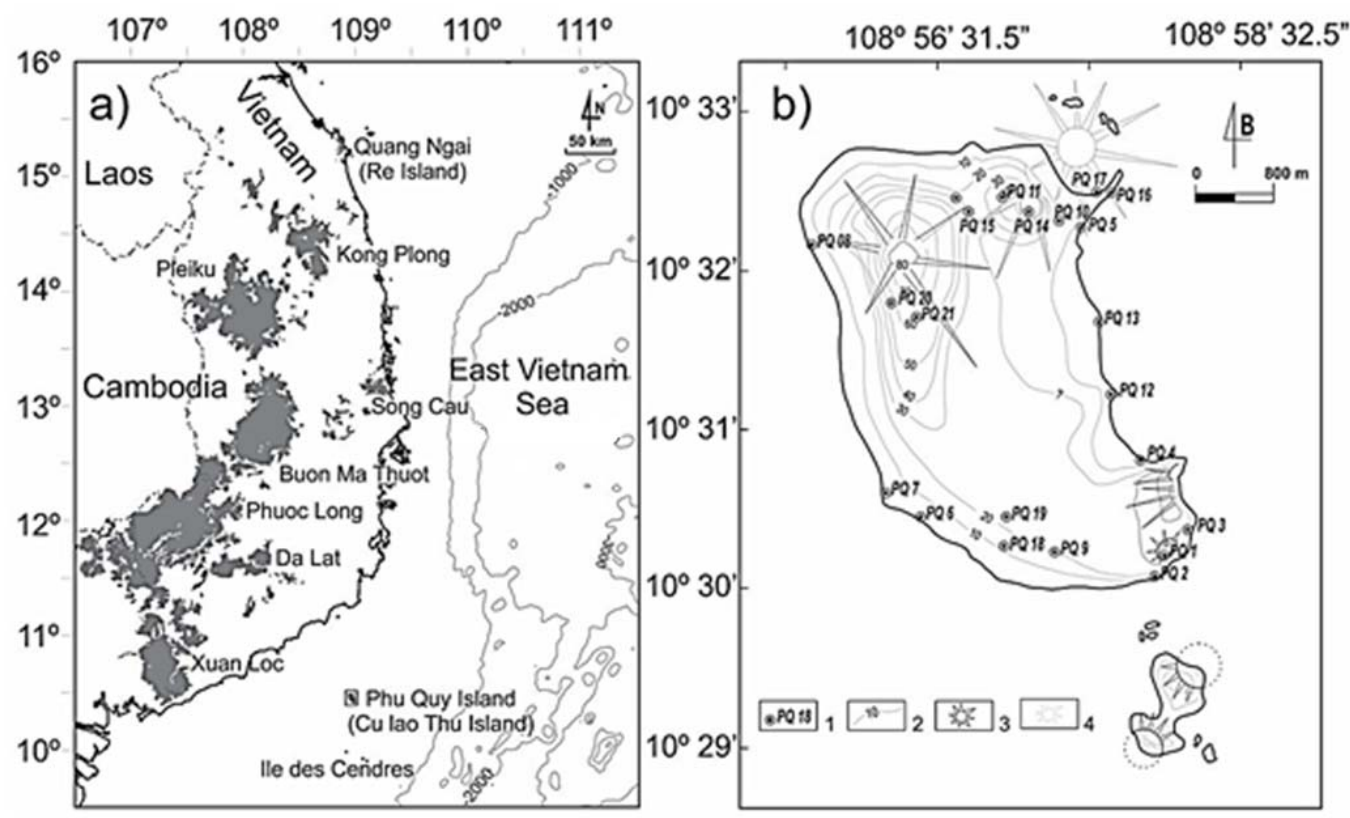

Figure 1. Location of Phu Quy island in the south-Central offshore of Vietnam (a) and a blow-up (b); shown are Cenozoic basaltic centers (shaded) in southern Vietnam and Western Highlands; also shown are (1) sampling sites and sample names, (2) iso-line contour, (3) central-type volcano, (4) supposed (marine) volcano. Distribution scheme is modified after Hoang et al. (1996); locations of volcanoes after field survey data

Field survey records show that the geological structure of the northern and eastern areas of Phu Quy island was strongly deformed and crushed, forming two structurally fractured zones oriented northeast-southwest and sub-meridian, respectively (Figure 2a). The NE-SW oriented destruction zone is thought to be an ancient fault and is clearly documented in the oil and gas seismic literature (Figure 2b) (Fyhn et al., 2009). This fracture zone is about $500 \mathrm{~m}$ wide with a $60^{\circ}$ direction forming a series of parallel fracture trends (Figure 2b). Although sub-meridian faults, according to seismic data, were recorded only in the vicinity of Phu Quy island (Figure 2b), the actual survey data at Phu Quy island, clearly record these faults also. These are smaller in size than the NE-SW faults forming depression zones, cutting young basalt layers (Figure 3b). Central cone volcanic eruptions occurred along the destruction zone (Figure 2a), suggesting volcanic activity may reactivate old fault systems (Rangin et al., 1995). 

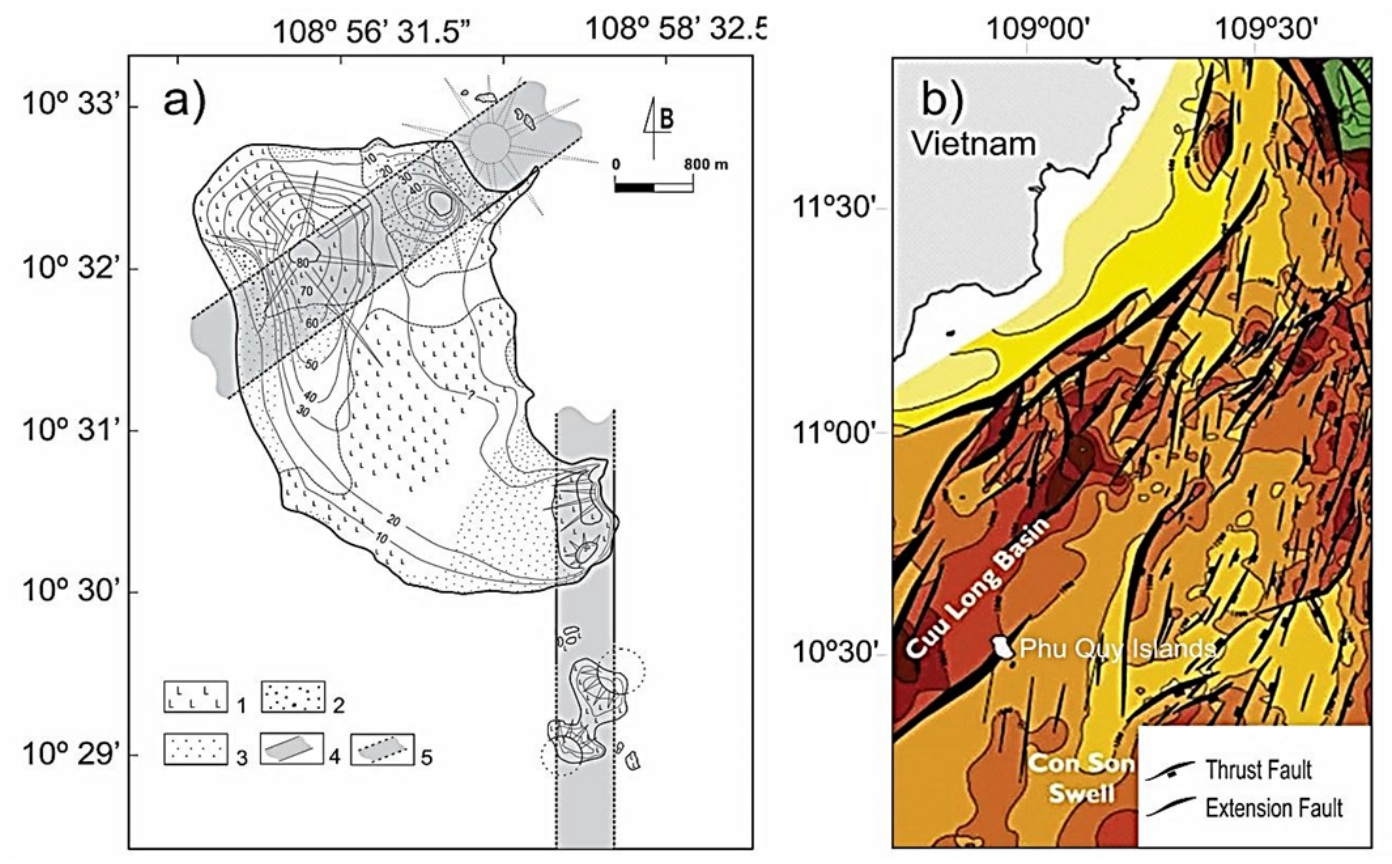

Figure 2. (a) Geological scheme of Phu Quy island simplified from Koloskov et al. (1989, 1999, 2016) and field survey data, (b) large NE-SW regional fault systems observed in the Phu Quy island area (after Fyhn et al., 2009); shown are basalt (1), welded pyroclastic deposits (2), soft, volcanic weathering products (3), volcanoes (4), supposed volcanoes (5), iso-line contour (6), defined faults (7), supposed faults (8). Age data are from Le and Hoang (2017)

\section{Sampling and sample processing}

The basalt samples were collected at 16 locations on Phu Quy island (Figure 3). Thin sections of the samples were prepared for microscopic study at the Institute of Geology and Geophysics.
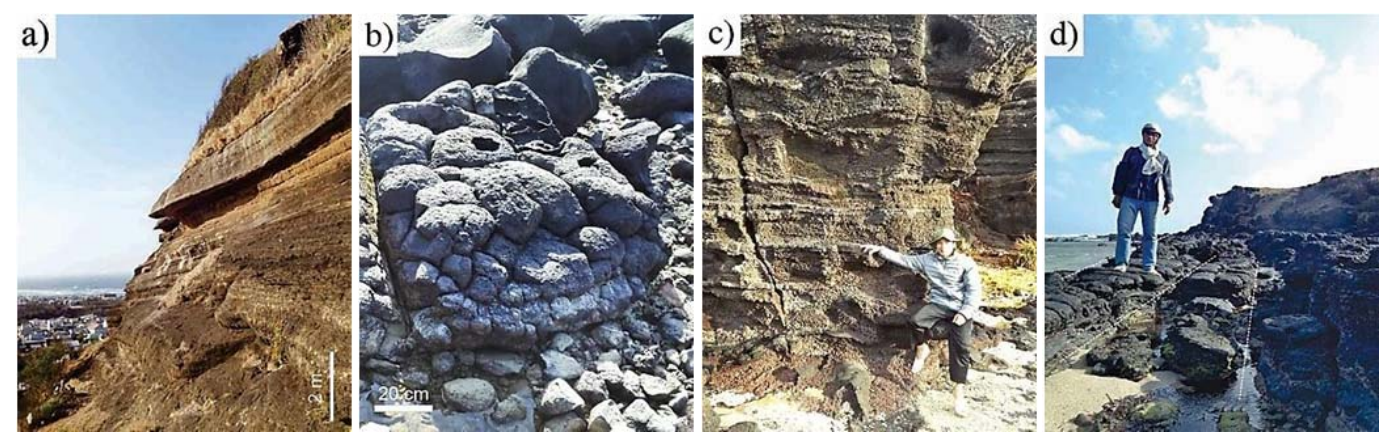

Figure 3. (a, c) pyroclastic layers including volcanic bomb, ash, breccia and tuff products, (b) outcrops of massive basaltic blocks (far back) and pillow basaltic lavas, (d) extension faults running in NE-SW direction cutting through basaltic outcrops in Phu Quy island 
For the chemical analyses, the samples were crushed into small chips about $1 \mathrm{~cm}$ by $1 \mathrm{~cm}$, repeatedly rinsed with clean water before being heated overnight in an oven at $100^{\circ} \mathrm{C}$ to reduce the effect of seawater, followed by rinsing with purified water before being dried in an oven. About 50g of the processed sample were crushed to $<2 \mathrm{~mm}$, about $25 \mathrm{~g}$ of which were extracted to be ground in an agate mill.

The major and trace element compositions were obtained from glass beads and pressed pellets using a Bruker Pioneer X-ray fluorescence analyzer at the Institute of Geological
Sciences, Vietnam Academy of Science and Technology (VAST). During the measurement process Geological Survey of Japan's geochemical standards were used to estimate the analytical precision and accuracy of the XRF analyzer. Five representative samples were re-analyzed at the Geological Survey of Japan, using a Panalytical XRF to evaluate the analytical precision and accuracy. In general, the analytical $1 \sigma$ errors are better than $\pm 0.5 \mathrm{wt} \%$ for the major oxides and the trace elements (ppm) are better than $\pm 6 \%$. The data are shown in Table 1.

Table 1. Major and trace element compositions, and mineralogical normative (CIPW) contents of the Phu Quy late Miocene - Pleistocene volcanic rocks

\begin{tabular}{|c|c|c|c|c|c|c|c|c|}
\hline Sample & PQ01 & PQ02 & PQ03 & PQ04 & PQ05 & PQ06 & PQ07 & PQ08 \\
\hline Rock type & alkali basalt & $\begin{array}{r}\text { olivine- } \\
\text { basalt }\end{array}$ & $\begin{array}{r}\text { olivine- } \\
\text { basalt }\end{array}$ & $\begin{array}{r}\text { olivine- } \\
\text { basalt }\end{array}$ & $\begin{array}{r}\text { olivine- } \\
\text { basalt }\end{array}$ & $\begin{array}{r}\text { olivine- } \\
\text { basalt }\end{array}$ & $\begin{array}{r}\text { olivine- } \\
\text { basalt }\end{array}$ & $\begin{array}{r}\text { olivine- } \\
\text { basalt }\end{array}$ \\
\hline$\overline{\mathrm{SiO}_{2}}$ & 49.22 & 49.43 & 49 & 49.87 & 51.12 & 51.2 & 51.13 & 50.47 \\
\hline $\mathrm{TiO}_{2}$ & 2.29 & 2.4 & 2.22 & 2.39 & 1.88 & 1.85 & 1.78 & 2.1 \\
\hline $\mathrm{Al}_{2} \mathrm{O}_{3}$ & 14.47 & 14.32 & 13.88 & 14.12 & 14.88 & 14.7 & 14.82 & 13.77 \\
\hline $\mathrm{FeO}^{*}$ & 11.32 & 11.21 & 11.94 & 11.44 & 11.27 & 11.39 & 11.37 & 11.88 \\
\hline $\mathrm{MnO}$ & 0.15 & 0.14 & 0.17 & 0.14 & 0.17 & 0.18 & 0.16 & 0.12 \\
\hline $\mathrm{MgO}$ & 7.45 & 7.23 & 7.3 & 5.94 & 6.95 & 6.99 & 6.99 & 6.5 \\
\hline $\mathrm{CaO}$ & 8.01 & 7.94 & 8.23 & 7.2 & 8.21 & 8.28 & 8.24 & 7.62 \\
\hline $\mathrm{Na}_{2} \mathrm{O}$ & 3.17 & 3.41 & 3.18 & 3.25 & 3.29 & 3.42 & 3.45 & 3.33 \\
\hline $\mathrm{K}_{2} \mathrm{O}$ & 2.4 & 1.64 & 1.9 & 2.62 & 1.28 & 1.2 & 1.23 & 1.4 \\
\hline $\mathrm{P}_{2} \mathrm{O}_{5}$ & 0.56 & 0.53 & 0.48 & 0.56 & 0.3 & 0.31 & 0.33 & 0.35 \\
\hline LOI & 0.79 & 1.44 & 1.23 & 1.96 & 0.25 & 0.21 & 0.23 & 2.03 \\
\hline Total & 98.9 & 98.1 & 98.1 & 97.6 & 99.3 & 99.4 & 99.3 & 97.4 \\
\hline \multicolumn{9}{|l|}{ CIPW } \\
\hline Di & 14.675 & 13.931 & 16.193 & 13.088 & 13.745 & 14.672 & 14.317 & 14.045 \\
\hline Нy & 0 & 4.531 & 1.031 & 4.769 & 13.883 & 12.178 & 11.149 & 15.203 \\
\hline $\mathrm{Ol}$ & 18.298 & 14.584 & 17.549 & 12.662 & 8.042 & 9.214 & 10.132 & 6.486 \\
\hline $\mathrm{Ne}$ & 0.85 & 0 & 0 & 0 & 0 & 0 & 0 & 0 \\
\hline$Q$ & 0 & 0 & 0 & 0 & 0 & 0 & 0 & 0 \\
\hline \multicolumn{9}{|c|}{ Trace element (ppm) } \\
\hline $\mathrm{Rb}$ & 54 & 14 & 38 & 67 & 28 & 26 & 25 & 30 \\
\hline $\mathrm{Sr}$ & 679 & 648 & 620 & 721 & 454 & 457 & 455 & 510 \\
\hline Y & 20 & 28 & 23 & 27 & 26 & 31 & 44 & 31 \\
\hline $\mathrm{Zr}$ & 220 & 270 & 180 & 270 & 136 & 135 & 135 & 160 \\
\hline $\mathrm{Nb}$ & 44 & 47 & 41 & 53 & 24 & 24 & 24 & 33 \\
\hline $\mathrm{Ba}$ & 597 & 434 & 534 & 583 & 402 & 427 & 335 & 352 \\
\hline $\mathrm{Cr}$ & 267 & 272 & 345 & 262 & 300 & 306 & 305 & 314 \\
\hline $\mathrm{Ni}$ & 211 & 189 & 240 & 212 & 210 & 226 & 221 & 212 \\
\hline $\mathrm{Zn}$ & 111 & 113 & 119 & 128 & 114 & 123 & 116 & 132 \\
\hline
\end{tabular}


Le Duc Anh, et al./Vietnam Journal of Earth Sciences 39 (2017)

\begin{tabular}{|c|c|c|c|c|c|c|c|c|}
\hline Sample & PQ10 & PQ12 & PQ13 & PQ16 & PQ17 & PQ19 & PQ20 & PQ21 \\
\hline $\begin{array}{l}\text { Rock } \\
\text { type }\end{array}$ & $\begin{array}{c}\text { olivine- } \\
\text { basalt }\end{array}$ & $\begin{array}{c}\text { olivine- } \\
\text { basalt }\end{array}$ & $\begin{array}{c}\text { olivine- } \\
\text { basalt }\end{array}$ & $\begin{array}{c}\text { olivine- } \\
\text { basalt }\end{array}$ & $\begin{array}{c}\text { olivine- } \\
\text { basalt }\end{array}$ & $\begin{array}{c}\text { olivine- } \\
\text { basalt }\end{array}$ & $\begin{array}{c}\text { olivine- } \\
\text { basalt }\end{array}$ & $\begin{array}{c}\text { olivine- } \\
\text { basalt }\end{array}$ \\
\hline $\mathrm{SiO}_{2}$ & 48.44 & 50.96 & 50.79 & 49.15 & 49.12 & 51.45 & 48.46 & 49.11 \\
\hline $\mathrm{TiO}_{2}$ & 2.75 & 1.91 & 1.89 & 2.46 & 2.6 & 1.84 & 2.37 & 2.15 \\
\hline $\mathrm{Al}_{2} \mathrm{O}_{3}$ & 13.49 & 14.43 & 14.55 & 14.73 & 13.69 & 14.53 & 14.66 & 14.45 \\
\hline $\mathrm{FeO}^{*}$ & 13.22 & 11.54 & 11.56 & 11.34 & 12.19 & 11.40 & 12.14 & 12.77 \\
\hline $\mathrm{MnO}$ & 0.13 & 0.16 & 0.15 & 0.14 & 0.14 & 0.15 & 0.15 & 0.15 \\
\hline $\mathrm{MgO}$ & 6.48 & 6.93 & 7.15 & 7.62 & 6.87 & 6.98 & 6.66 & 6.09 \\
\hline $\mathrm{CaO}$ & 7.18 & 8.25 & 8.23 & 7.57 & 7.84 & 8.19 & 7.42 & 7.5 \\
\hline $\mathrm{Na}_{2} \mathrm{O}$ & 3 & 3.42 & 3.2 & 3.16 & 3.04 & 3.3 & 2.98 & 3.14 \\
\hline $\mathrm{K}_{2} \mathrm{O}$ & 2.3 & 1.26 & 1.26 & 2.26 & 2.21 & 1.24 & 2.22 & 1.4 \\
\hline $\mathrm{P}_{2} \mathrm{O}_{5}$ & 0.49 & 0.31 & 0.27 & 0.47 & 0.48 & 0.33 & 0.55 & 0.37 \\
\hline LOI & 2.39 & 0.49 & 0.32 & 0.88 & 1.71 & 0.09 & 2.15 & 2.62 \\
\hline Total & 97.3 & 99.2 & 99.2 & 98.8 & 98.1 & 99.2 & 97.6 & 96.9 \\
\hline \multicolumn{9}{|l|}{ CIPW } \\
\hline Di & 13.12 & 15.308 & 14.347 & 12.395 & 15.285 & 14.233 & 10.839 & 11.269 \\
\hline Hy & 5.611 & 11.068 & 13.823 & 0.482 & 4.229 & 15.925 & 5.168 & 14.186 \\
\hline $\mathrm{Ol}$ & 14.565 & 9.756 & 8.516 & 18.863 & 14.531 & 6.589 & 15.315 & 8.472 \\
\hline $\mathrm{Ne}$ & 0 & 0 & 0 & 0 & 0 & 0 & 0 & 0 \\
\hline$Q$ & 0 & 0 & 0 & 0 & 0 & 0 & 0 & 0 \\
\hline \multicolumn{9}{|c|}{ Trace element (ppm) } \\
\hline $\mathrm{Rb}$ & 64 & 29 & 30 & 43 & 57 & 28 & 35 & 33 \\
\hline $\mathrm{Sr}$ & 757 & 459 & 464 & 667 & 713 & 457 & 718 & 547 \\
\hline $\mathrm{Y}$ & 34 & 52 & 24 & 26 & 29 & 35 & 40 & 40 \\
\hline $\mathrm{Zr}$ & 229 & 139 & 135 & 233 & 224 & 139 & 230 & 156 \\
\hline $\mathrm{Nb}$ & 55 & 25 & 25 & 48 & 50 & 25 & 51 & 36 \\
\hline $\mathrm{Ba}$ & 628 & 346 & 405 & 553 & 572 & 366 & 571 & 410 \\
\hline $\mathrm{Cr}$ & 310 & 305 & 308 & 262 & 290 & 300 & 290 & 352 \\
\hline $\mathrm{Ni}$ & 217 & 254 & 246 & 212 & 238 & 233 & 249 & 202 \\
\hline $\mathrm{Zn}$ & 143 & 124 & 119 & 122 & 131 & 115 & 132 & 134 \\
\hline
\end{tabular}

\section{Analytical result}

\subsection{Petrography}

The Phu Quy island basalts are mostly massive, porphyritic with phenocrysts of olivine ( 5 to $12 \mathrm{vol} \%$ ). The olivine phenocrysts are euhedral or subhedral, tablet or broken fragments with sizes ranging from $0.1 \times$ $0.5 \mathrm{~mm}$ to $1 \times 2 \mathrm{~mm}$. Some olivine crystals are altered, being replaced partly or completely by iddingsite. The groundmass is intersertal, micro-doleritic, containing microcrysts of olivine, clinopyroxene, plagioclase, ore minerals and volcanic glass (Figure 4).

\subsection{Major element compositions}

According to the CIPW normative compositions (Table 1), except for PQ01 sample containing nepheline (Ne)-normative, which is an alkaline basalt, the remaining samples are quartz (Qz)- bearing free (subalkaline) olivine basalt (Figure 5a, b). The basalts define two geochemical groups. One is high- $\mathrm{SiO}_{2}$ $(50-52 \mathrm{wt} \%)$, low-MgO, $-\mathrm{TiO}_{2}(<2.2 \mathrm{wt} \%)$ $\mathrm{P}_{2} \mathrm{O}_{5}(<0.4 \mathrm{wt} \%)$ and low $-\mathrm{K}_{2} \mathrm{O}(<1.5 \mathrm{wt} \%)$, termed as 'low alkaline - high silica' group, comprising samples PQ05, PQ06, PQ07, PQ08, PQ12, PQ13, PQ19 and PQ21. These were collected along the coastline, produced by early volcanic phase (Figures. 1b, 5b). The other is "high alkaline - low silica" group, having low- $\mathrm{SiO}_{2}(<50 \mathrm{wt} \%)$, high-MgO, $\mathrm{TiO}_{2} \quad(2.2-2.8 \mathrm{wt} \%) \quad-\mathrm{P}_{2} \mathrm{O}_{5} \quad(>0.45-0.55 w t \%)$ and high- $\mathrm{K}_{2} \mathrm{O}(1.5$ - 2.5wt\%), comprising samples PQ01, PQ02, PQ03, PQ04, PQ10, PQ16 and PQ17. These were sampled near 
volcanic craters, belonging to the later eruptive phase. The high- and low- $\mathrm{SiO}_{2}$ contents correlate negatively with the corresponding $\mathrm{MgO}$, from 6 to $7 \mathrm{wt} \%$ and from 6.5 to $7.6 \mathrm{wt} \%$, respectively (Figure 6 ). The other oxides, however, do not show clear correlations with $\mathrm{MgO}$. The $\mathrm{SiO}_{2}$ concentrations in melts depend mainly on melting pressure, the higher the pressure, the lower the $\mathrm{SiO}_{2}$ content; while $\mathrm{MgO}$ is dependent on both pressure and partial melting temperature, the higher the pressure and/or temperature, the higher the $\mathrm{MgO}$ content (Takahashi and Kushiro, 1983; Hirose and Kushiro, 1993). Other major elements such as $\mathrm{K}_{2} \mathrm{O}$, $\mathrm{TiO}_{2}$ and $\mathrm{P}_{2} \mathrm{O}_{5}$ behave like trace elements, whose contents are higher if the melting source is comparably more enriched and/or if the degree of partial melting is lower (Hirose and Kushiro, 1993; Turner and Hawkesworth, 1995; Kushiro, 1996, 1998; Kogiso et al., 1998).The above observations suggest that the basaltic melt of early eruptive phase may have originated from a relatively depleted and/or refractory source, under relatively low melting pressure and high degree of partial melting. In contrast, the later eruptive phase could have been derived from a relatively enriched and/or fertile source, under higher melting pressure temperatures and lower degree of partial melting.
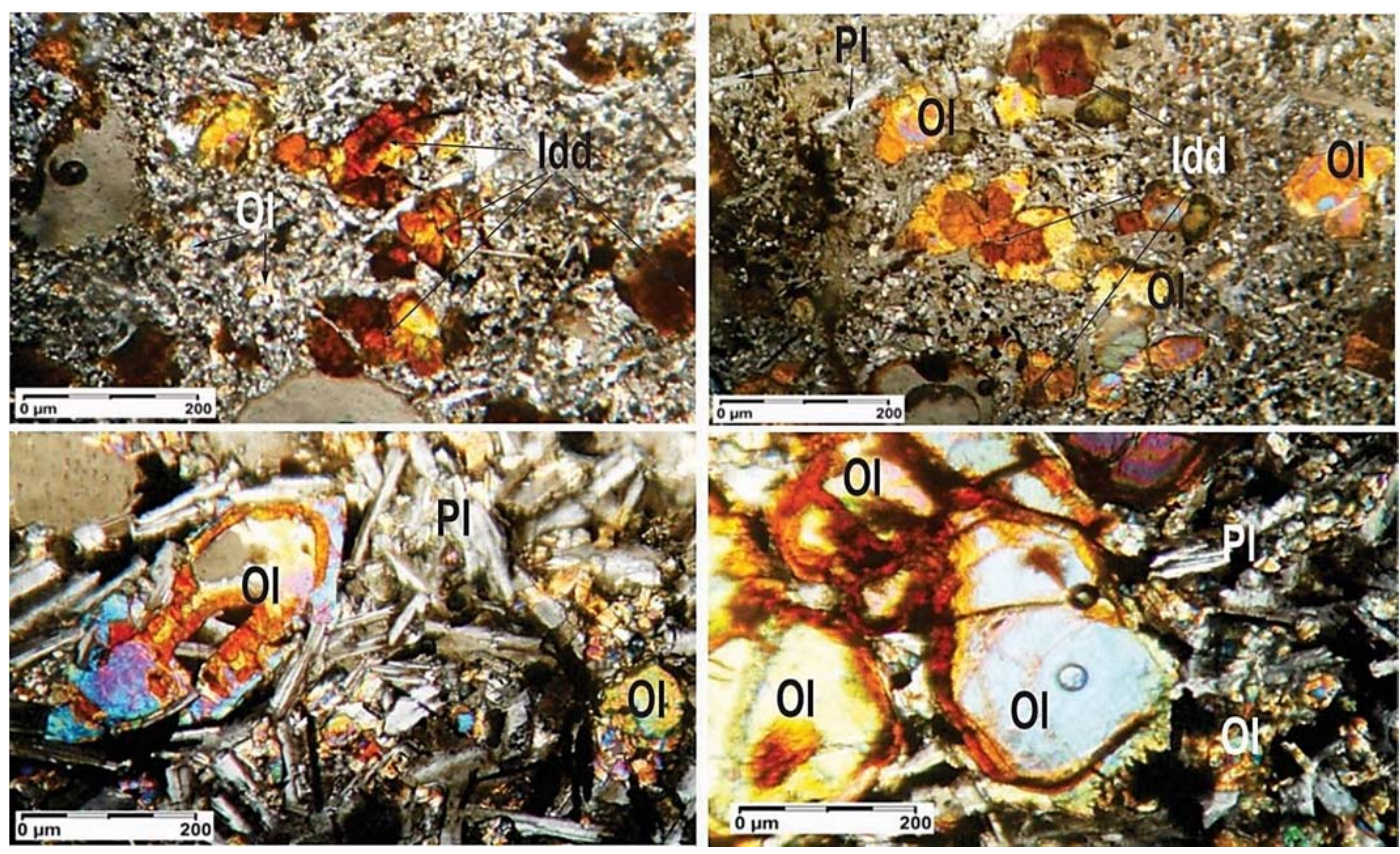

Figure 4. Phu Quy sub-alkaline (olivine) phyric basalt with intersertal (upper row) and doleritic (lower row) texture, showing phenocrysts of olivine partially replaced by iddingsite. Abbreviations Ol: olivine, Idd: iddingsite, Pl: plagioclase 
a)

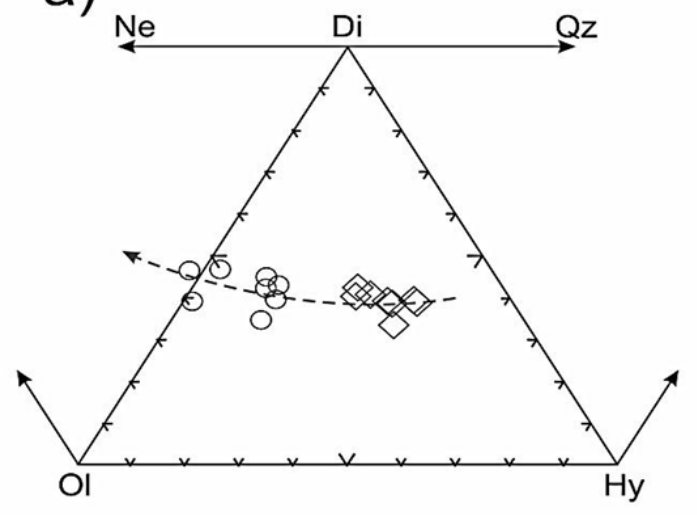

b)

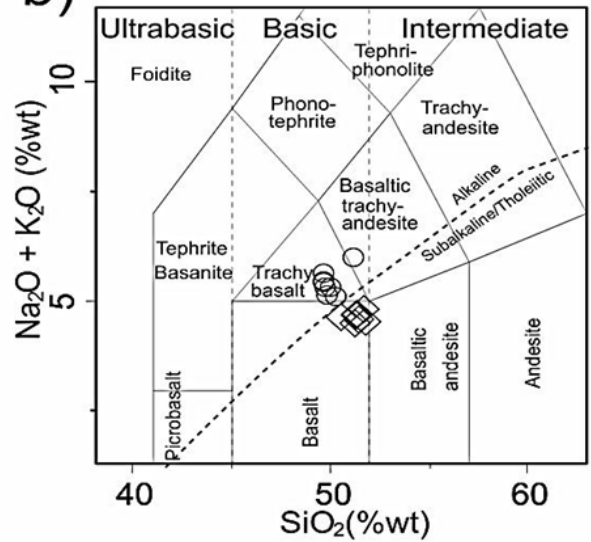

Figure 5. Classification diagram after CIPW normative compositions (after Cross et al., 1903) (a) and TAS (total alkalis versus $\mathrm{SiO}_{2}$ ) (after La Bas et al., 1986) of the Phu Quy basalts; younger lavas (circles) have higher alkalis and more olivine content (closer to nepheline apex). Arrow shows evolutional trend. Ne: nepheline, Di: diopside, Qz: quartz, Ol: olivine, Hy: hypersthene
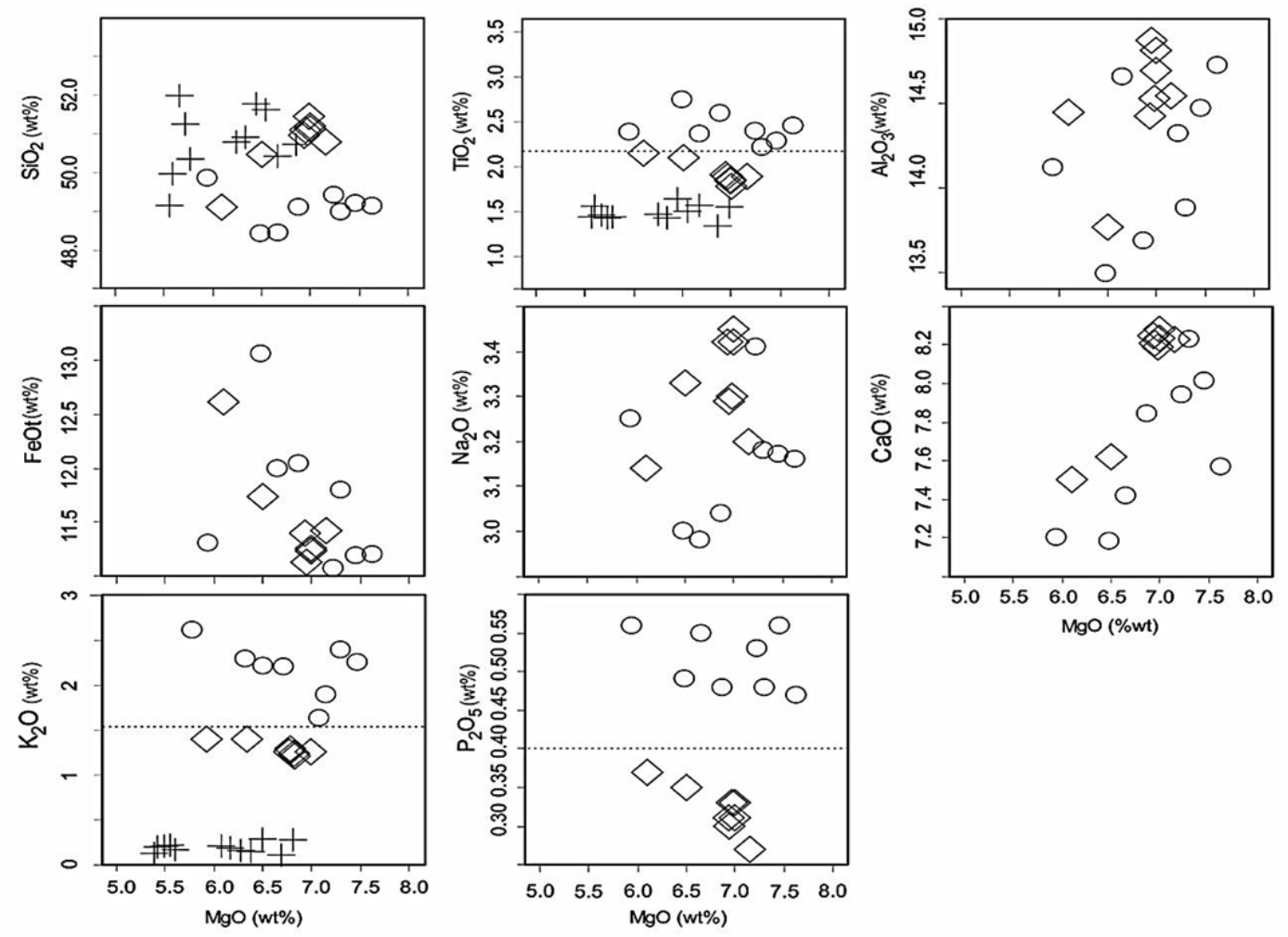

Figure 6. Plots of $\mathrm{MgO}$ (wt.\%) against major oxides of Phu Quy basalts; except for $\mathrm{SiO}_{2}$ which shows two broadly negative correlation trends with $\mathrm{MgO}$ for early and later eruptive lavas, the other oxides such as $\mathrm{K}_{2} \mathrm{O}, \mathrm{TiO}_{2}$ and $\mathrm{P}_{2} \mathrm{O}_{5}$ define higher and lower fields, respectively, for late (circle) and early (diamond) lavas. Plotted for comparison are synopening East Vietnam Sea (cross, after Li et al., 2014) showing even lower in $\mathrm{MgO}, \mathrm{TiO}_{2}$ and $\mathrm{K}_{2} \mathrm{O}$ than Phu Quy basalts 


\subsection{Trace element compositions}

The primitive mantle normalized trace element distribution patterns (after Sun and McDonough, 1989) have typical intraplate basalt-like signatures with a smooth decrease from highly incompatible to relatively immobile elements (Figure 7). However, the difference in trace element concentrations between the two basaltic groups is significant. For example, $\mathrm{Rb}$ content varies from 35 to $56 \mathrm{ppm}$ as compared to $<35 \mathrm{ppm}$; Sr from 650 to 760 ppm compared to $450-510$ ppm; Ba from 430 to $630 \mathrm{ppm}$ (most $>550 \mathrm{ppm}$ ) as compared to 335 to $410 \mathrm{ppm}$; and $\mathrm{Zr}>220 \mathrm{ppm}$ as compared to $135 \mathrm{ppm}$, respectively, in the late 'high alkaline - low silica' and early 'low alkaline - high silica' basaltic groups (Table 1). The trace element compositions of late basaltic series are closely comparable to Pleiku youngest $(<1-0.3 \mathrm{Ma})$ basalts in the Western Highlands, while those of Phu Quy early basalts are quite similar to Pleiku second youngest (5-2 Ma) basalts (Figure 7; Hoang, 2005a; Hoang et al., 2013) and are more enriched as compared to Pleiku $>6 \mathrm{Ma}$ basalts. The latter is believed to be derived from the relatively refractory and depleted lithospheric mantle, in contrast to the later 5-2 Ma and $<1-0$. Ma basaltic rocks which could have been derived from more fertile and enriched source under very high melting pressures, possibly in the asthenosphere (Hoang, 2005a, b; Hoang et al., 2013).

\section{Discussion}

\subsection{Mantle geochemical characteristics}

\subsubsection{Crustal material interaction}

Basaltic magma is less viscous as compared to highly silicic magma, often pouring on the surface rapidly as lava flows or as explosive pyroclastic deposits under the effect of high pressure. Therefore, the probability of crustal contamination in many cases is low. However, we should take into consideration the large distance from the melt segregation point to the surface, averaging by as much as $45 \mathrm{~km}$ to $90 \mathrm{~km}$, for the tholeiitic and basaltic magmas, respectively (Kushiro, 1990, 1996), or long residence time and magma fractional crystallization at intermediate magma chambers in the crust that can interact with the wall-rock material. In addition, mantle sources can be contaminated with crustal material being introduced into the mantle by sub ducting slabs.

The prevalence of crustal contamination is reflected in the ratios of the elements considered to be rich in crustal material such as $\mathrm{Ba}$, $\mathrm{Rb}, \mathrm{K}, \mathrm{Si}, \mathrm{Al}, \ldots$ and poor in the high field strength elements (HFSE) such as Zr, Y, Ti, and Nb,... (Taylor and McLennan, 1991; Fontaine and Rudnik, 1995). Crustal material contamination is therefore characterized by positive linear correlations between, for example, $\mathrm{Ba}$ and $\mathrm{Ba} / \mathrm{Nb}$ with $\mathrm{SiO}_{2}$. However, the negative correlation between $\mathrm{Ba}(\mathrm{ppm})$ and $\mathrm{SiO}_{2}$ and positive correlation between $\mathrm{Ba} / \mathrm{Nb}$ and $\mathrm{SiO}_{2}$ as shown in Figure 8 may rule out crustal contamination. With the trace element distribution pattern viewed as typical for the intraplate basalt (Figure 7), the correlation between $\mathrm{Ba}$ and $\mathrm{Ba} / \mathrm{Nb}$ with $\mathrm{SiO}_{2}$ reflects the enrichment or depletion nature of source domain in combination with the effect of melting pressures and temperatures, and degrees of partial melting (Takahashi and Kushiro, 1983; McKenzie and O'Nion, 1991; Scarrow and Cox, 1995; Kogiso et al., 1998; Kamenetski et al., 2012).

\subsubsection{Mantle geochemistry}

Although accounting for just under $1 \%$ by weight of the total rock mass, the trace elements fully reflect the source characteristics, melting mechanisms, fractional crystallization processes from the time they are generated until the moment they appear on the surface (Hofmann, 1988; Sun and McDonough, 1989; Kogiso et al., 1998). 


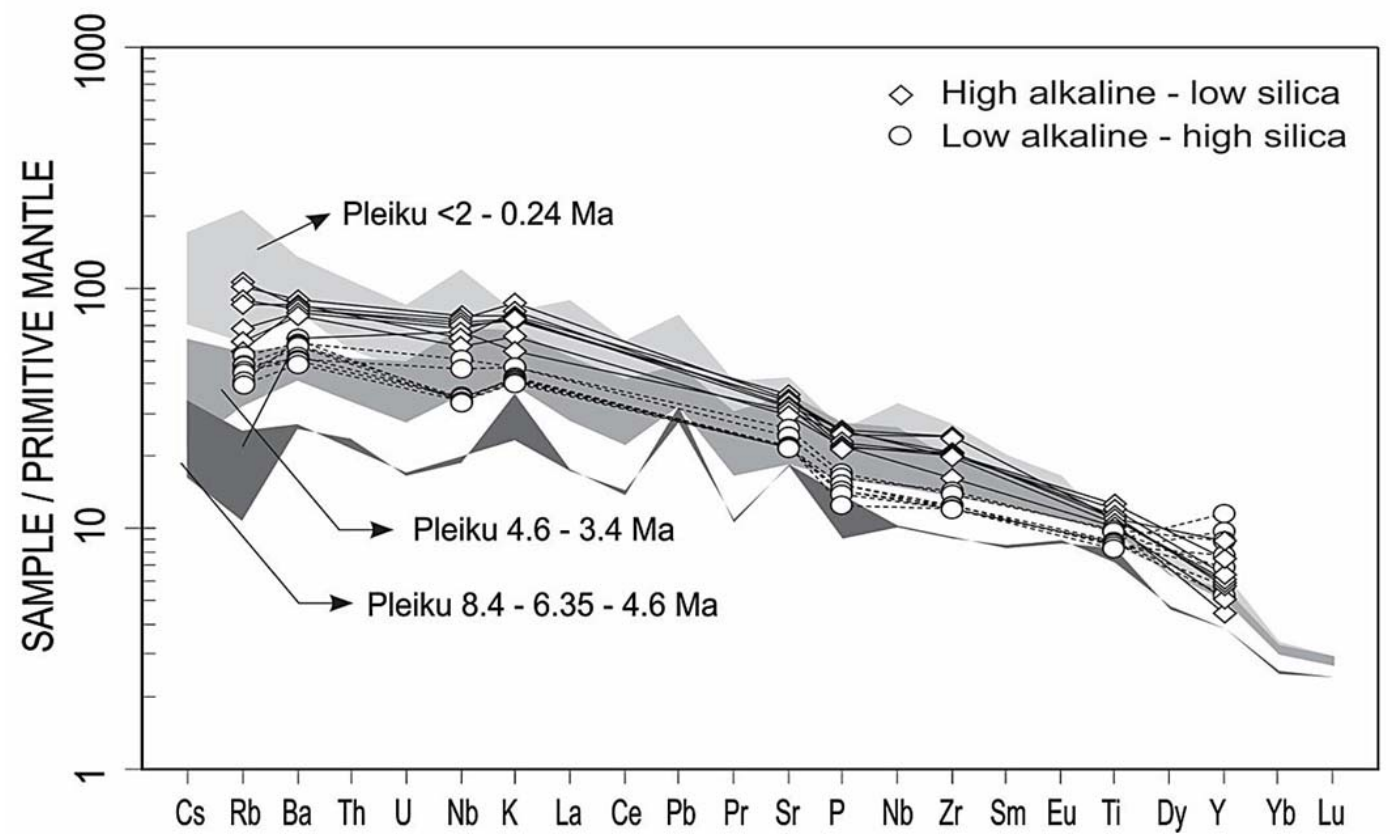

Figure 7. Primitive mantle normalized trace element distribution diagram for early and late Phu Quy basalts, shown for comparison are Pleiku basalts erupted at 8.4 - 4.6 Ma, 4.6- 3.4 Ma and <2 - $0.24 \mathrm{Ma}$ (after Hoang et al., 2013). The trace element patterns of the Phu Quy basalts are closely similar to enriched Pleiku basalts younger than 4.6 Ma
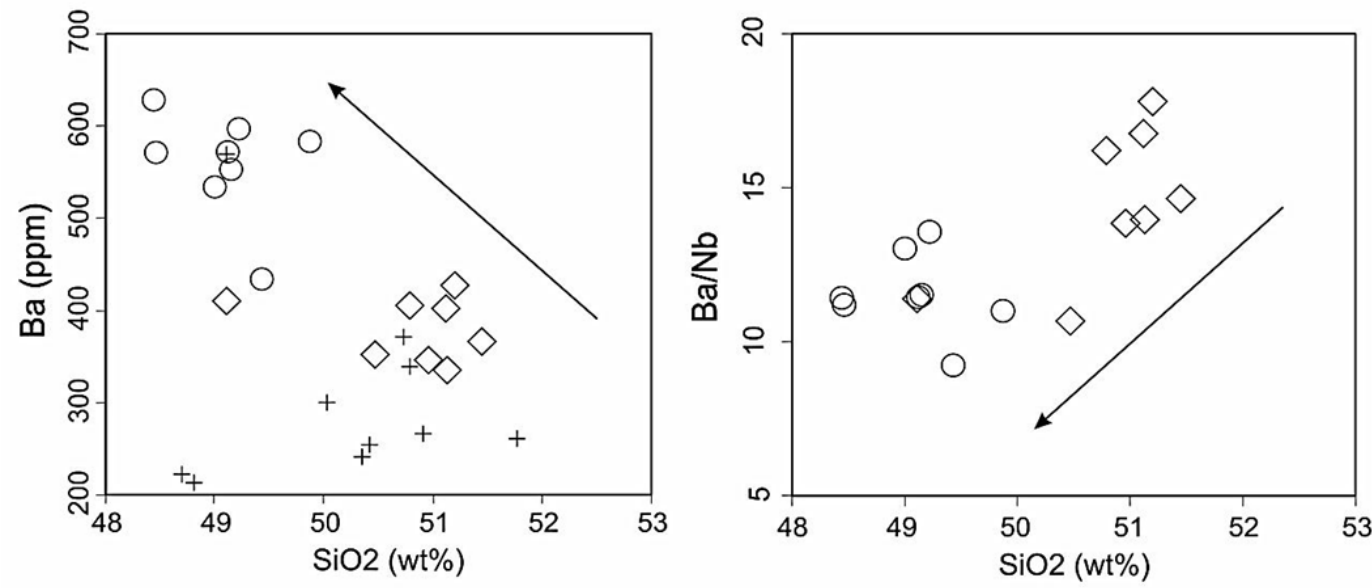

Figure 8. Negative and positive correlation between $\mathrm{SiO}_{2}$ and, respectively, $\mathrm{Ba}$ (a) and $\mathrm{Ba} / \mathrm{Nb}$ (b) for early (diamond) and late (circle) Phu Quy basalts; also plotted are syn-opening East Vietnam Sea (after Li et al., 2014). Higher Ba accompanying lower $\mathrm{SiO}_{2}$ and lower $\mathrm{Ba} / \mathrm{Nb}$ (e.g. higher $\mathrm{Nb}$ ) accompanying lower $\mathrm{SiO}_{2}$ may suggest effect of high melting pressure and/or low degrees of partial melting. Arrow shows temporal evolution trend

The positive correlation between the $\mathrm{Nb} / \mathrm{Y}$ and $\mathrm{Zr} / \mathrm{Y}$ ratios of the two basalt groups distributed along the limit field of $\Delta \mathrm{Nb}(\Delta \mathrm{Nb}$ $=1.74+\log (\mathrm{Nb} / \mathrm{Y})-1.92 \log (\mathrm{Zr} / \mathrm{Y}))$ is an index reflecting the melting of mantle sources, the nature of source enrichment or depletion 
and the possibility of crustal contamination (Fitton et al., 1997; Hoang et al., 2016).The "low alkaline - high silica" basaltic group is characterized by low $\mathrm{Nb} / \mathrm{Y}$ and low $\mathrm{Zr} / \mathrm{Y}$, distributed near the mid-ocean ridge basalt field, both depleted (N-MORB) and enriched mantle (E-MORB) (Kogiso et al., 1998; Relegous et al., 1999) (Figure 9), which is quite similar to the Dak Mil Neogene basalt (Dak Nong province, Western Highlands) (Hoang et al., 2013), that is interpreted to have been derived from a relatively depleted and refractory litho- sphere mantle or from sources that have undergone previous melting. The Phu Quy "high alkaline - low silica" basaltic group is distributed near the Hawaii and North Arch oceanic island basalt fields (after Norman and Garcia, 1999; Frey et al., 2000), and plotted in Pleiku Pleistocene field (Hoang, 2005a, Hoang et al., 2013) (Figure 9). This distribution field is usually explained by the magma being generated from enriched and fertile mantle sources (Hirose and Kushiro, 1993; Scarrow and Cox, 1995; Kushiro, 1996, 1998).

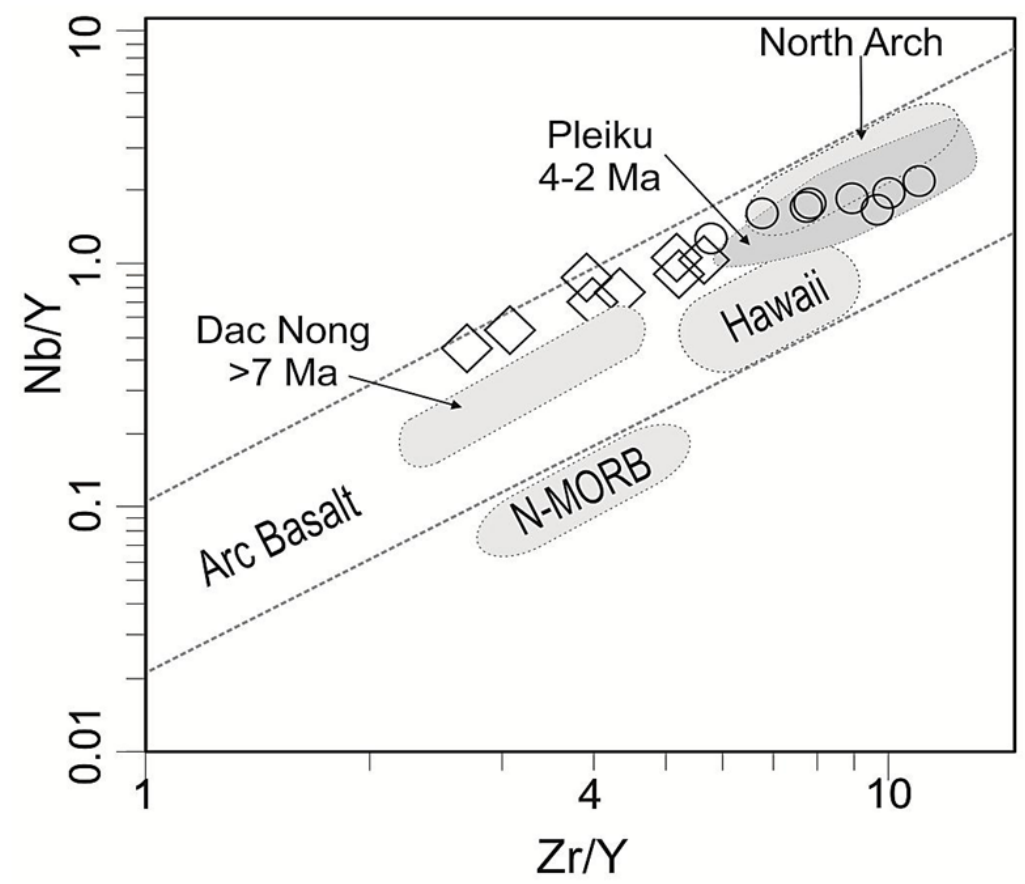

Figure 9. Plots of $\mathrm{Nb} / \mathrm{Y}$ versus $\mathrm{Zr} / \mathrm{Y}$ for Phu Quy basalts; shown are fields of Pleiku 4-2 Ma lavas, Dak Nong $>7 \mathrm{Ma}$ (after Hoang et al., 2013), North Arch alkaline basalts (Frey et al., 2000), Hawaiian picrites (Norman and Garcia, 1999), Depleted Mid-Ocean Ridge Basalts (N-MORB) (Regelous et al., 1999), Arc basalt, for comparison. The Phu Quy lavas are relatively enriched and plotted in the field of intraplate volcanic geochemistry

The high field strength elements such as $\mathrm{Nb}, \mathrm{Zr}$ and $\mathrm{Y}$ are not affected by the weathering process and considered to reflect the geochemistry of the source and the tectonic setting of magma occurrence. Of the above elements, the distribution coefficient between the solid and the liquid phase $\left(\mathrm{K}_{\mathrm{d}}\right)$ of $\mathrm{Nb}$ is much smaller than $\mathrm{Zr}$, the latter is smaller than $\mathrm{Y}$ (Hofmann, 1988; Sun and McDonough, 1989). Therefore, the $\mathrm{Nb} / \mathrm{Y}$ and $\mathrm{Zr} / \mathrm{Y}$ ratios may vary depending on the degree of partial melting. Note that the clearly negative linear relationship is found only between $\mathrm{SiO}_{2}$ and $\mathrm{MgO}$ (Figure 6), while the other oxides do not 
exhibit a clear linear relationship with $\mathrm{MgO}$. For basaltic rocks that occur in a small area having a similarity in eruption age, the unclear linearity in the geochemical relationship can only be explained by the difference in degrees of partial melting, melting pressures and/or temperatures, producing different eruption episodes, regardless of their having been derived from the same mantle source. Thus, the linear relationship between $\mathrm{Nb} / \mathrm{Y}$ and $\mathrm{Zr} / \mathrm{Y}$ may be due to the difference in the melting degree and fractional crystallization processes of different melt portions generated from a single source mantle (e.g. McKenzie and Bickle, 1988; McKenzie and O'Nion, 1991).

\subsection{Mantle dynamic model}

The formation and development of $\mathrm{Phu}$ Quy island was based on the relationship between mantle dynamics (temperature and pressure) and the regional tectonic context resulting in melt generation and volcanic eruption (e.g. Latin and White, 1990). Based on the chemical compositions of the volcanic rocks, it is possible to determine the composition of the primitive melt, indirectly determining the mantle temperature and pressure (McKenzie and Bickle, 1988).

\subsubsection{Decompression melting: mantle dynam- ics versus lithospheric extension}

Volcanic activities in the continental shelf of Vietnam is considered to be related to lithospheric extension processes triggered by deep-seated fault systems (Li et al., 2013; Franke et al., 2013; Sava et al., Carter et al., 2000). The processes were believed to combine with extruding mantle flows followed the Neo-Tethys closure as a result of the IndoEurasian collision (Flower et al., 1998, 2001; Hoang and Trinh, 2009; Yan et al., 2014).

The mantle melting occurs normally as a result of extensional tectonic activity occurring in a large area and having a profound effect on the lithosphere mantle. Typical decompression melting producing basaltic melt occurs beneath the oceanic rift, that serves as a diverging boundary of two plates moving away from each other under the influence of two subduction zones and the combined effect of pushing force by basaltic lava having been formed as a result of the rifting process. Lithospheric extension occurs in two general forms, namely, uniform stretching and simple shear stretching (Latin and White, 1990). An extensional value is defined as $\beta$ factor, the ratio between the original to extended lithospheric thickness. Under normal mantle thermal condition, e.g. $1280^{\circ} \mathrm{C}$, melting under the effect of uniform stretching is only possible if $\beta>2.8$, while there is no melting under pure shear stretching (McKenzie and Bickle, 1988; Latin and White, 1990). However, in higher mantle thermal conditions, for example, $1480^{\circ} \mathrm{C}$, a uniform stretching can cause mantle melting with a $\beta$ factor as small as 1.5 (compared to 4 of simple shear stretching).

Seismic and deep borehole data acquired along and near the fossil spreading axis in the NE, Central and SW sub-basins of East Vietnam Sea revealed basalt and pyroclastic deposits interbedded with early Miocene (>16 Ma) sediments (Li et al., 2014, 2015). However, the rate and extent of the synspreading volcanism were modest, corresponding to slower to intermediate spreading rate $(20 \mathrm{~km}$ to $35 \mathrm{~km} / \mathrm{Myr})$; although the spreading rate sometimes reached 70-80 km/Myr (Li et al., 2014; IODP 349 Scientific report, 2014). Detailed studies of the seismic and magmatic cross-sections in the southwestern sub-basin of East Vietnam Sea, revealed numerous submarine volcanoes that mostly appeared after $5 \mathrm{Ma}$, about 10 million years after the cessation of the spreading of the East Vietnam Sea (Li et al., 2013; 2014; 2015; Ding et al., 2016). In particular, these eruptions do not appear to be associated with any major tectonic phase in the area ( $\mathrm{Li}$ et al., 2013). Also, when studying the regional extension faults, these authors concluded that 
the extension factor $(\beta)$ hardly surpassed 2.8 to trigger melting of the mantle having a normal thermal state (e.g. $1280^{\circ} \mathrm{C}$ ); therefore, $\mathrm{Li}$ et al. (2013) proposed that upper mantle dynamics rather than lithospheric tectonics caused mantle melting and magmatism in the SW sub-basin (Li et al., 2013; 2014).

Neogene - Quaternary basaltic volcanism is widespread in many areas in the Western Highlands, mainly from about 7 million years (Hoang, 2005a; Hoang and Flower, 1998; Hoang et al., 1996; 2013), following the uplift of the territory. The basaltic layers cover an area of thousands of square kilometers, up to several hundred meters thick, distributed at intersections, or along the regional extension fault zones, with sub-meridian being the major direction (Rangin et al., 1995). There are no comprehensive studies evaluating the extent of lithospheric extension and accompanying extension factor values of the fault systems in the Western Highlands of Vietnam. But studies of extension fault systems between longitudes $109^{\circ}$ and $110^{\circ} \mathrm{E}$, running from south of the Gulf of Bac Bo (Northern Gulf) southward to Con Co and Ly Son volcanic islands, to Phu Quy island then Ile des Cendres submarine volcanic group (Koloskov et al., 2016 and references therein), with a Moho plane at depth of about $28 \mathrm{~km}$, shows a $\beta$ factor of about 1.3 (Nguyen et al., 2004; Nguyen and Nguyen, 2013). This extension value is much too small to trigger mantle melting under the normal thermal state (e.g. $1280^{\circ} \mathrm{C}$, after Latin and White, 1990; see Carter et al., 2000).

Tamaki (1995), followed by Flower et al. (1998; 2001), on the basis of deep seismic tomography data, proposed that the collision of Indian subcontinent with Eurasia in the late Eocene led to the closure of the Neo-Tethys situated in between the plates, which not only deformed the lithosphere but also generated the east-west directed asthenospheric flows (Tamaki, 1995; Yang and Liu, 2009, and references therein). These asthenospheric flows not only caused mantle melting and magmatism from the Paleogene to the present time in East and Southeast Asia, but also acted as a major driver in the opening of the Western Pacific marginal seas, including East Vietnam Sea (Flower et al., 1998; 2001; 2013; Hoang and Flower, 1998; Hoang et al., 2013; 2014). While the extension factor in the East Vietnam (South China) Sea region and the Western Highlands of Vietnam is not large enough to cause decompression melting, a hotter-than-normal mantle (i.e. $1380^{\circ} \mathrm{C}$ ) caused by the extrusion of asthenospheric flows is sufficient to trigger melting and magmatism, and also to generate various mineral resources in the SW sub-basin (Li et al., 2013; 2014; 2015; Ding et al., 2016).

\subsubsection{Primitive melts}

The geochemical composition of melt formed by partial melting of mantle peridotite is strongly correlated with the melting pressure and temperature, the degree of partial melting and the source geochemistry (McKenzie and Bickle, 1988; McKenzie and O'Nion, 1991). For example, the $\mathrm{SiO}_{2}$ content depends on the melting pressure, the lower the $\mathrm{SiO}_{2}$ content is, the higher the melting pressure. The $\mathrm{FeO}$ content is proportional to the melting temperature and the source chemistry; the more fertile the source is, the higher the $\mathrm{FeO}$. The $\mathrm{MgO}$ content is proven to be proportional to the degree of partial melting (Takahashi and Kushiro, 1983; Hirose and Kushiro, 1993; Kushiro, 1996; 1998). Two trends of negative correlations between $\mathrm{SiO}_{2}$ and $\mathrm{MgO}$ observed in the major elemental diagrams (Figure 6) represent two high and low melting pressure ranges, forming, respectively, low and high $\mathrm{SiO}_{2}$ groups. Elements like $\mathrm{K}, \mathrm{Na}$ and $\mathrm{Ti}$ depend on the degree of partial melting, the lower is the degree, the higher is their content (Kushiro, 1996; 1998). Therefore, the low $\mathrm{SiO}_{2}$ content accompanied by high concentrations of $\mathrm{Na}_{2} \mathrm{O}, \mathrm{K}_{2} \mathrm{O}$ and $\mathrm{TiO}_{2}$ 
(and vice versa) suggests that the melt generation below Phu Quy island occurred in at least two major phases. The early phase was controlled by low melting pressure and high melting degree (low alkalinity - high silica); while the later stage operated under high pressure and low melting degree (high alkalinity - low silica). The continuity between high- low melting pressures and low- high melting degrees is also illustrated by the negative correlation between $\mathrm{SiO}_{2}$ and $\mathrm{Ba}$ (and positive correlation with $\mathrm{Ba} / \mathrm{Nb}$ ) (Figure 8), and also the positive relationship between $\mathrm{Zr} / \mathrm{Y}$ and $\mathrm{Nb} / \mathrm{Y}$. (Figure 9), which may reflect the mixing process of mantle sources through column melting (Kamenetski et al., 2012).

In order to re-establish the primitive basalt composition of Phu Quy island, we apply a mathematical model based on the principle of olivine addition to basalt compositions having
$\mathrm{MgO}$ content higher than $6 \mathrm{wt} \%$ (Scarrow and Cox, 1995; Turner and Hawkesworth, 1995; Hoang and Flower, 1998, 2013, 2016). Olivine is compensated incrementally $0.1 \%$ (after Yamashita et al., 1996), using the Fe-Mg distribution coefficient $\left(\mathrm{Kd}^{(\mathrm{Fe} / \mathrm{Mg})}\right)$ between olivine and the melt of about 0.30 (Roeder and Emslie, 1970; Takahashi and Kushiro, 1983) and forsterite $\left(\mathrm{Mg} /\left(\mathrm{Mg}+\mathrm{Fe}^{2+}\right)\right.$ of olivine in the residue is approximately 0.90 (Hirose and Kushiro, 1993). The rationale for this calculation is, first, that olivine with $\mathrm{Fo}_{83-89}$ is the major phenocryst observed in the Phu Quy basalt having $\mathrm{MgO}>6 \%$; second, basalt with $\mathrm{MgO}>6 \%$ is generally less affected by pyroxene and plagioclase fractionation (Turner and Hawkesworth, 1995; Hoang and Flower, 1998; Hoang et al., 2013). The computed compositions of primitive melts are presented in Table 2.

Table 2. Computed primitive melts of the Phu Quy basalts

\begin{tabular}{|c|c|c|c|c|c|c|c|c|}
\hline Sample & PQ05 & PQ06 & PQ07 & PQ08 & PQ12 & PQ13 & PQ19 & PQ21 \\
\hline$\overline{\mathrm{SiO}_{2}}$ & 49.42 & 49.41 & 49.36 & 49.42 & 49.34 & 49.26 & 49.66 & 48.30 \\
\hline $\mathrm{TiO}_{2}$ & 1.59 & 1.56 & 1.50 & 1.77 & 1.62 & 1.60 & 1.55 & 1.80 \\
\hline $\mathrm{Al}_{2} \mathrm{O}_{3}$ & 12.51 & 12.33 & 12.44 & 11.56 & 12.15 & 12.27 & 12.20 & 12.06 \\
\hline $\mathrm{FeO}^{*}$ & 11.95 & 12.04 & 12.02 & 12.88 & 12.24 & 12.24 & 12.08 & 13.97 \\
\hline $\mathrm{MnO}$ & 0.17 & 0.18 & 0.16 & 0.13 & 0.16 & 0.15 & 0.15 & 0.16 \\
\hline $\mathrm{MgO}$ & 13.12 & 13.13 & 13.15 & 13.31 & 13.07 & 13.29 & 13.12 & 13.06 \\
\hline $\mathrm{CaO}$ & 6.93 & 6.97 & 6.94 & 6.42 & 6.97 & 6.96 & 6.91 & 6.29 \\
\hline $\mathrm{Na}_{2} \mathrm{O}$ & 2.76 & 2.87 & 2.89 & 2.79 & 2.88 & 2.69 & 2.77 & 2.62 \\
\hline $\mathrm{K}_{2} \mathrm{O}$ & 1.07 & 1.01 & 1.03 & 1.17 & 1.06 & 1.06 & 1.04 & 1.17 \\
\hline $\mathrm{P}_{2} \mathrm{O}_{5}$ & 0.25 & 0.26 & 0.28 & 0.29 & 0.26 & 0.23 & 0.28 & 0.31 \\
\hline Total & 99.78 & 99.76 & 99.77 & 99.74 & 99.75 & 99.76 & 99.76 & 99.72 \\
\hline Sample & PQ01 & PQ02 & PQ03 & PQ04 & PQ10 & PQ16 & PQ17 & PQ20 \\
\hline $\mathrm{SiO}_{2}$ & 48.14 & 48.57 & 48.14 & 48.83 & 47.69 & 48.14 & 48.19 & 47.78 \\
\hline $\mathrm{TiO}_{2}$ & 1.98 & 2.07 & 1.91 & 2.00 & 2.32 & 2.13 & 2.22 & 2.02 \\
\hline $\mathrm{Al}_{2} \mathrm{O}_{3}$ & 12.44 & 12.29 & 11.90 & 11.74 & 11.33 & 12.69 & 11.64 & 12.42 \\
\hline $\mathrm{FeO}^{*}$ & 11.88 & 11.91 & 12.63 & 12.49 & 14.23 & 11.89 & 12.99 & 13.05 \\
\hline $\mathrm{MnO}$ & 0.15 & 0.14 & 0.17 & 0.15 & 0.14 & 0.14 & 0.14 & 0.16 \\
\hline $\mathrm{MgO}$ & 13.04 & 13.20 & 13.15 & 13.15 & 13.13 & 13.21 & 13.01 & 13.14 \\
\hline $\mathrm{CaO}$ & 6.91 & 6.84 & 7.08 & 6.01 & 6.05 & 6.54 & 6.69 & 6.31 \\
\hline $\mathrm{Na}_{2} \mathrm{O}$ & 2.72 & 2.92 & 2.72 & 2.70 & 2.52 & 2.72 & 2.58 & 2.52 \\
\hline $\mathrm{K}_{2} \mathrm{O}$ & 2.06 & 1.41 & 1.63 & 2.17 & 1.93 & 1.94 & 1.88 & 1.88 \\
\hline $\mathrm{P}_{2} \mathrm{O}_{5}$ & 0.48 & 0.45 & 0.41 & 0.46 & 0.41 & 0.40 & 0.41 & 0.47 \\
\hline Total & 99.81 & 99.81 & 99.76 & 99.71 & 99.74 & 99.82 & 99.76 & 99.74 \\
\hline
\end{tabular}

Using CMAS $\left(\mathrm{CaO}-\mathrm{MgO}-\mathrm{Al}_{2} \mathrm{O}_{3}-\mathrm{SiO}_{2}\right)$ tetrahedral diagrams of Walker et al. (1979), and the sub-solidus curves constructed from exper- imental results (Hirose and Kushiro, 1993; Kushiro, 1996, 1998), the primitive melt compositions projected from the diopside apex on to the 
Ol-Pl-Q plane show melting pressures ranging from $18-20 \mathrm{~kb}$ to $25 \mathrm{~kb}$ (Figure 10). As shown above, Phu Quy island's basalts, being quite primitive (with $\mathrm{MgO}>6 \mathrm{wt} \%$ ), may be formed from the same fertile and enriched source
(Figure 9). The relatively close melting pressure range may suggest melts of the early and later phases may be produced by melting of mantle peridotites at different pressures (depths) in the same mantle source.

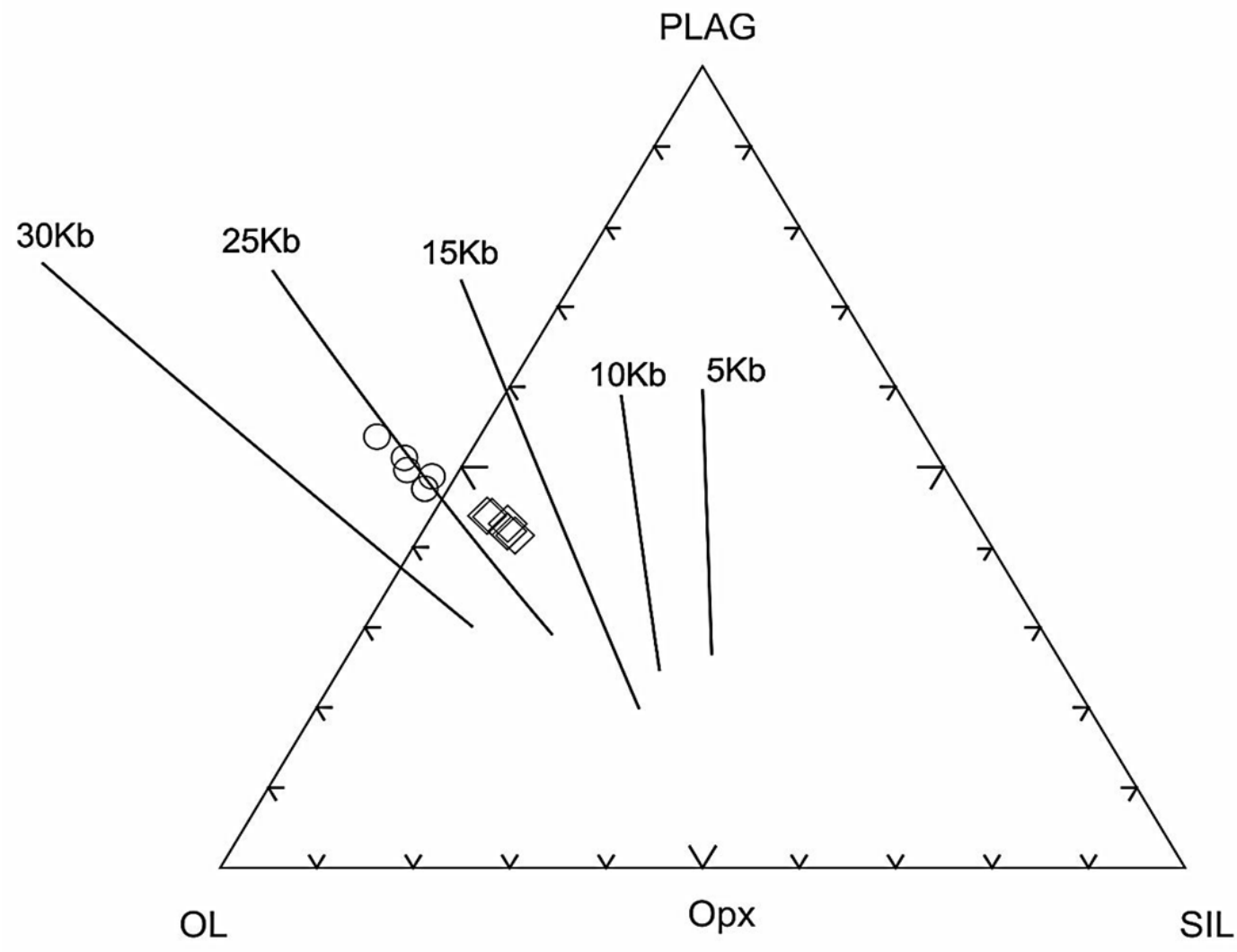

Figure 10. Projections of computed primitive melt compositions on to Pl -Ol-Sil plane (after Walker et al., 1979), showing melting pressures of Phu Quy lavas ranging between about 18 to $25 \mathrm{~Kb}$. Sub-solidus lines are constructed using experimental results of Hirose and Kushiro (1993), Kushiro (1996, 1998), (after Yamashita et al., 1996)

\section{Summary and Conclusions}

From the above descriptions we come to the following conclusions:

The late Miocene-Pleistocene volcanic rocks of Phu Quy island form two geochemical groups. One is low-alkaline high-silica olivine basalt, forming the base of the volcanic island. The other is high alkaline-low silica alkaline basalt, characterized by stratovolcano-type eruptions.
The trace element ratios such as $\mathrm{Ba} / \mathrm{Nb}$, $\mathrm{Ba} / \mathrm{Zr}$ and $\mathrm{Ba} / \mathrm{Y}$ of the early basalts are much higher compared to the later eruptive rocks, possibly due to the higher degree of partial melting. The $\mathrm{Nb} / \mathrm{Y}, \mathrm{Zr} / \mathrm{Y}$ ratios and accompanying $\mathrm{MgO}, \mathrm{K}_{2} \mathrm{O}, \mathrm{TiO}_{2}$ and $\mathrm{P}_{2} \mathrm{O}_{5}$ contents are relatively low, suggesting that they may be derived from a relatively depleted and refractory source, possibly in the lithospheric mantle. The later (younger) alkaline basalts show- 
ing geochemical features contrasting with the early basalts such as higher $\mathrm{TiO}_{2}, \mathrm{P}_{2} \mathrm{O}_{5}$, and $\mathrm{MgO}$, and lower $\mathrm{SiO}_{2}$ may be derived from a deeper and more enriched source, for example, asthenosphere. However, the continuity in the negative correlation between ratios such as $\mathrm{Ba} / \mathrm{Nb}$ and $\mathrm{Nb} / \mathrm{Y}$ versus $\mathrm{SiO}_{2}$ (or positive with $\mathrm{MgO}$ ) suggests that both series of Phu Quy basalt may also be produced from the same mantle source due to the effect of variable melting pressures.

Neogene-Quaternary volcanic activity in the south- Central Vietnam continental shelf and elsewhere in Vietnam was unrelated to an important regionally tectonic phase. The infiltration of asthenospheric flows, the consequence of Neo-Tethys closure following the collision of India and Eurasia, not only readily raises the mantle temperature to melt, but may also appear as an important driving force in the marginal sea openings, including the East Vietnam Sea.

The melting pressures calculated based on the computed primitive melt compositions suggest that the early phase basaltic melt may be formed from 18 to $20 \mathrm{~kb}$ (ca. 55-60 km) and the later phase may be generated between 20 and $25 \mathrm{~kb}$ (about 60 to $75 \mathrm{~km}$ ). The decompression polybaric melting of a single mantle source may have facilitated mixing among different melt portions to form linear geochemical relationships observed between two basaltic groups.

\section{Acknowledgements}

This paper was conducted under a project within the framework of prioritized scientific and technological research projects of the Vietnam Academy of Science and Technology 'Study of geochemistry and petrology of basalts in the coastal and offshore areas in south- Central Vietnam with implications to mantle and lithospheric dynamics' coded VAST.06.04/17-18.
Proofreading and valuable suggestions by Rolando Pena (UP at Quezon) are gratefully acknowledged.

\section{References}

Baker M.B., Hirschmann M.M., Ghiorso M.S., Stolper E.M., 1995. Compositions of near-solidus peridotite melts from experiments and thermodynamic calculations. Nature 375, 308-311.

Baker M.B., Stolper E.M., 1994. Determining the composition of high pressure mantle melts using diamond aggregates. Geochimica et Cosmochimica Acta 58, 2811-2827.

Carter A., Roques D., Bristow C.S., 2000. Denudation history of onshore central Vietnam: constraints on the Cenozoic evolution of the western margin of the South China Sea. Tectonophysics 322, 265-277.

Ding W., Li J., Clift P.D., \& Expedition I.O.D.P., 2016. Spreading dynamics and sedimentary process of the Southwest Sub-basin, South China Sea: constraints from multi-channel seismic data and IODP Expedition 349. Journal of Asian Earth Sciences, 115, 97-113.

Fitton J.G., Saunders A.D., Norry M.J., Hardarson B.S., Taylor R.N., 1997. Thermal and chemical structure of the Iceland plume. Earth and Planetary Science Letters 153, 197-208.

Flower M.F.J., Zhang M., Tu K., Xie G.H., Chen C.Y., 1992. Magmatism in the South China Basin 2.Postspreading Quaternary basalts from Hainan Island, South China. Chemical Geology 97, 65-87.

Flower M., Tamaki K., Hoang N., 1998. Mantle Extrusion: A model for Dispersed Volcanism and DUPAL-like Asthenosphere in East Asia and the Western Pacific. In: Mantle dynamics and plate Interactions in East Asia, edited by: Flower, $\mathrm{M}$ et al., Geodynamic 27, 67-88.

Flower M.F.J., Russo R.M., Tamaki K., Hoang Nguyen, 2001. Mantle contamination and the Izu-BoninMariana (IBM) 'high-tide mark', evidence for mantle extrusion caused by Tethyan closure. Tectonophysics 333, 9-34.

Franke D., Savva D., Pubellier M., Steuer S., Mouly B., Auxietre J.L., Meresse F., Chamot L.R., 2013. The final rifting evolution in the South China Sea. Marine and Petroleum Geology xxx, 1-17. 
Vietnam Journal of Earth Sciences, 39(3), 270-288

Fyhn M.B.W., Boldreel L.O., Nielsen L.H., 2009. Geological development of the Central and South Vietnamese margin: implications for the establishment of the South China Sea, Indochinese escape tectonics and Cenozoic volcanism. J. Tectonophysics, 478 (3-4), 184-214.

Hirose K., Kushiro I., 1993. Partial melting of dry peridotites at high pressures: determination of compositions of melts segregated from peridotite using aggregates of diamond. Earth and Planetary Science Letters 114, 477-489.

Hofmann A.W., 1988. Chemical differentiation of the Earth: the relationship between mantle, continental crust, and oceanic crust. Earth and Planetary Science Letters 90, 297-314.

Kamenetski V.S., Chung S.-L., Kamenetski M.B., Kuzmin D.V., 2012. Picrites from the Emeishan large igneous province, SW China: a compositional continuum in primitive magmas and their respective mantle sources. Journal of Petrology 53 (N10), 2095-2113.

Kogiso T., Hirose K., Takahashi E., 1998. Melting experiments on homogeneous mixtures of peridotite and basalt: Application to the genesis of ocean island basalts. Earth and Planetary Science Letters 162, 45-61.

Koloskov A.V., 1999. Ultrabasic inclusions and volcanics as a self-regulated geologic system. Nauchnyi Mir, Moscow (in Russian).

Koloskov A.V., Fedorov P.I., Rashidov V.A., 2016. New data on products composition of the Quaternary volcanic activity in the shelf zone of NW margins of the South China Sea and the problem of asthenospheric diapirism.

Koloskov A.V., Flerov G.B., Sharas'kin A.Y., 1989. Rift-Related Volcanism in the System of Eastern Asian Volcanic Belts. In Magmatism of Rifts: Petrology, Evolution, Geodynamics, Ed. by O. A. Bogatikov, Nauka, Moscow, 139-144 (in Russian).

Koloskov A.V., Rashidov V.A., Gatinskii Y.G., et al., 2003. Late Cenozoic volcanism in the continental shelf zones of Vietnam. In Proceedings of the Annual Conference Devoted to the Day of Volcanologists. Naukadlya Kamchatki, Petropavlovsk Kamchatskii, 9-15 (in Russian).
Kudrass H. R., Hiedicke M., Cepek P., Kreuzer H., and Müller P., 1986. Mesozoic and Cenozoic rocks dredged from the South China Sea (Reed Bank area) and Sulu Sea and their significance for plate tectonic reconstructions. Mar. Pet. Geol.3, 19-30.

Kushiro I., 1990. Partial melting of mantle wedge and evolution of island arc crust. Journal of Geophysical Research 95, 15929-15939.

Kushiro I., 1996. Partial melting of a fertile mantle peridotite at high pressures: An experimental study using aggregates of diamond. In Basu A., and Hart S., eds. Earth processes: Reading the isotopic clock: American Geophysical Union Geophysical Monograph 95, 109-122.

Kushiro I., 1998. Compositions of partial melts formed in mantle peridotites at high pressures and their relation to those of primitive MORB. Physics of the Earth and Planetary Interiors 107, 103-110.

Latin D., White N., 1990. Generating melt during lithospheric extension: uniform vs. simple shear. Geology 18, 327-331.

Le Bas M.J., Le Maitre R.W., Streckeisen A., Zanettin B., 1986. A chemical classification of volcanic rocks based on the total alkali-silica diagram. Journal of Petrology 27, 745-750.

Le Duc Anh, Nguyen Hoang, 2017. Geochemistry of Cenozoic basalts in the south-Central Vietnam coastline region: implications for regional mantle lithosphere interaction. Vietnam Journal of Earth Sciences, in preparation.

Lee T.Y., Lo C-H., Chung S-L., Chen C-Y., Wang L., Lin W-P., Nguyen Hoang, Cung Thuong Chi, Nguyen Trong, Yem, 1998. ${ }^{40} \mathrm{Ar} /{ }^{39} \mathrm{Ar}$ dating result of Neogene basalts in Vietnam and its tectonic implication. In: Flower, M.F.J., et al. (Eds.), Mantle Dynamics and Plate Interactions in East Asia. Geodynamics Series, vol. 27, American Geophysics Union, 317-330.

Li C.-F., et al., 2014. Ages and magnetic structures of the South China Sea constrained by deep tow magnetic surveys and IODP Expedition 349, Geochem. Geophys. Geosys., 15, 4958-4983.

Li C-F., et al., 2015. Seismic stratigraphy of the central South China Sea basin and implications for neotectonics. J. Geophys. Res. Solid Earth, 120, 1377-1399. Doi:10.1002/2014JB011686. 
Le Duc Anh, et al./Vietnam Journal of Earth Sciences 39 (2017)

Li C.-F., Lin J., Kulhanek D.K., 2013. South China Sea tectonics: Opening of the South China Sea and its implications for southeast Asian tectonics, climates, and deep mantle processes since the late Mesozoic, IODP SCI. Prosp., 349.

Li L., Clift P., Nguyen The Hung, 2013. The sedimentary, magmatic and tectonic evolution of the southwestern South China Sea revealed by seismic stratigraphic analysis. Marine Geophysical Research 34, 341-365.

Li L., Clift P.D., Stephenson R., Nguyen T.H., 2014. Non-uniform hyper-extension in advance of seafloor spreading on the Vietnam continental margin and the SW South China Sea. Basin Research 26, 106-134.

Malinovsky A.I., Rashidov V.A., 2015. Compositional characteristics of sedimentary and volcanosedimentary rocks of Phu Quy-Catwickisland group in the continental shelf of Vietnam. Bulletin of Kamchatka Regional Association of 'Educational Scientific' Center, Earth Sciences 27 (3), 12-34 (in Russian with English summary).

McKenzie D., Bickle M.J., 1988. The volume and composition of melt generated by extension of the lithosphere. Journal of Petrology 26, 625-679.

McKenzie D., O’Nions R.K., 1991. Partial melt distribution from inversion of rare earth element concentrations. Journal of Petrology 32, 1021-1091.

Nguyen Hoang, 2005a. Source characteristics and melting conditions of Cenozoic basalts from Pleiku, south-central Vietnam. Journal of Geology Series A 286, 15-22 (in Vietnamese with English abstract).

Nguyen Hoang, 2005b. Lithospheric mantle beneath Pleiku: evidence from mantle xenolith. Journal of Geology Series A 287, 8-19 (in Vietnamese with English abstract).

Nguyen Hoang, Flower M.F.J., 1998. Petrogenesis of Cenozoic basalts from Vietnam: implication for origins of a diffuse igneous province. J. Petrol. 39, 369-395.

Nguyen Hoang, Flower M.F.J., Carlson R.W., 1996. Major, trace element, and isotopic compositions of Vietnamese basalts: interaction of enriched mobile asthenosphere with the continental lithosphere? Geochimica et Cosmochimica Acta 60, 4329-4351.

Nguyen Hoang, Uto K., 2003. Geochemistry of Cenozoic basalts in the Fukuoka district (northern
Kyushu, Japan), implications for asthenosphere and lithospheric mantle interaction. Chemical Geology 198, 249-268.

Nguyen Hoang, Phan Trong Trinh, 2009. Overview of petrologic and geochemical characteristics of Neogene-Quaternary basalts in the East Vietnam Sea and neighboring regions and their related mantle dynamics. Journal of Geology, 312A, 39-57 (in Vietnamese with English abstract).

Nguyen Hoang, Flower M.F.J., Cung Thuong Chi, Pham Tich Xuan, Hoang Van Quy, Tran Thanh Son, 2013. Collision-induced basalt eruptions at Pleiku and Buon Me Thuot, south-central Viet Nam. Journal of Geodynamics 69, 65-83.

Nguyen Hoang, Ogasawara M., Tran Thi Huong, Phan Van Hung, Nguyen Thi Thu, Cu Sy Thang, Pham Thanh Dang, Pham Tich Xuan, 2014. Geochemistry of Neogene basalts in the Nghia Dan district, western Nghe An. Vietnam Journal of Earth Sciences 36(4), 403-412. DOI: 10.15625/08667187/36/4/6428.

Nguyen Hoang, Tran Thi Huong, Ogasawara M., Le Duc Anh, Nguyen Thi Mai, Nguyen Thi Thu, Cu Sy Thang, Le Thi Phuong Dung, 2016. Petrography and geochemistry of Permian basalts of the Cam Thuy formation and their relation to Song $\mathrm{Da}$ and Emeishan magmatic rocks. Vietnam Journal of Earth Sciences 38, 372-392. DOI: 10.15625/08667187/38/4/8993.

Nguyen Nhu Trung, Lee S.M., Bui Cong Que, 2004. Satellite gravity anomalies and their correlation with the major tectonic features in the South China Sea. Gondwana Research 7(2), 407-424.

Nguyen Nhu Trung, Nguyen Thi Thanh Huong, 2013. Topography of the Moho and Earth crust structure beneath the East Vietnam Sea from 3D inversion of granite field data. Acta Physica 61(2), 357-384.

Norman M.D, Garcia M.O., 1999. Primitive magmas and source characteristics of the Hawaiian plume: petrology and geochemistry of shield picrites. Earth and Planetary Science Letters 168, 27-44.

Pearce J.A., Norry M.J., 1979. Petrogenetic implications of $\mathrm{Ti}, \mathrm{Zr}, \mathrm{Y}$, and $\mathrm{Nb}$ variations in volcanic rocks. Contributions to Mineralogy and Petrology 69, $33-47$. 
Vietnam Journal of Earth Sciences, 39(3), 270-288

Rangin C. Huchon, Le Pichon X., Bellon H., Lepvrier C., Roques D., Hoe N.D., Quynh V., 1995. Cenozoic deformation of central and south Vietnam. Tectonophysics 251, 179-196.

Regelous M., Niu Y., Wendt J.I., Batiza R., Greig A., Collerson K.D., 1999. Variations in the geochemistry of magmatism on the East Pacific Rise at $10^{\circ} 30^{\prime} \mathrm{N}$ since $800 \mathrm{ka}$. Earth Planet. Sci. Lett. 168, 45-63.

Roeder P.L., Emslie R.F., 1970. Olivine-liquid Equilibrium. Contributions to Mineralogy and Petrology 29, 275-289.

Ru K., Pigott J.D., 1986. Episodic rifting and subsidence in the South China Sea. AAPG Bull 70(9), 1136-1155.

Rudnik R.L., Fontaine D.M., 1995. Nature and composition of the continental crust: a lower crustal perspective. Review Geophysics, 33, 267-309.

Sava D., Pubellier M., Franke D., Chamot-Rooke N., Meresse F., Steuer S., Auxietre J.L., 2014. Different expressions of rifting on the South China Sea margins. Marine and Petroleum Geology 58, 579-598.

Scarrow, J.H., Cox, K.G., 1995. Basalts generated by decompressive adiabatic melting of a mantle plume: a case study from the Isle of Skye, NW Scotland. Journal of Petrology 36, 3-22.

Sun S.S., McDonough W.F., 1989. Chemical and isotopic systematics of oceanic basalts: implications for mantle composition and processes. In: Saunders, A.D., Norry, M.J. Eds. Magmatism in Ocean Basins. Geol. Soc. Spec. Publ., London, 313-345.

Takahashi E., Kushiro I., 1983. Melting of a dry peridotite at high pressures and basalt magma genesis. American Mineralogist 68(9-10), 859-879.

Tamaki K., 1995. Upper mantle extrusion tectonics of southeast Asia and formation of western Pacific backarc basins. In: International Workshop: Cenozoic Evolution of the Indochina Peninsula,
Hanoi/Do Son, April, p.89 (Abstract with Programs).

Taylor S.R., McLennan S.M., 1985. The continental crust: Its composition and evolution. Blackwell Scientific Publishers, Oxford.

Tran Duc Luong, Nguyen Xuan Bao, 1981. Geological map 1:500.000 of Vietnam.

Tu K., Flower M.F.J., Carlson R.W., Zhang M., Xie G.H., 1991. $\mathrm{Sr}, \mathrm{Nd}$, and $\mathrm{Pb}$ isotopic compositions of Hainan basalts (South China), implications for a subcontinental lithosphere DUPAL source. Geology 19(6), 567-569.

Tu K., Flower M.F.J., Carlson R.W., Zhang M., Xie G.H., 1992. Magmatism in the South China Basin, 1.Isotopic and trace element evidence for an endogenous Dupal mantle component. Chemical Geology 97, 47-63.

Turner S., Hawkesworth C., 1995. The nature of the subcontinental mantle: constraints from the major element composition of continental flood basalts. Chemical Geology 120, 295-314.

Walker D., Shibata T., DeLong D.E., 1979. Abyssal tholeiites from the Oceanographer Fracture Zone III. Phase equilibria and mixing. Contributions to Mineralogy and Petrology 70, 111-125.

Yamashita S., Tatsumi Y., Nohda S., 1996. Temporal variation in primary magma compositions in the northeast Japan Arc, The Island Arc5, 276-288.

Yan Q., Shi X., Castillo R.B., 2014. The late MesozoicCenozoic tectonic evolution of the South China Sea: A petrologic perspective. Journal of Asian Earth Sciences 85, 178-201.

Yang Y., Liu M., 2009. Crustal thickening and lateral extrusion during the Indo-Asian collision: a $3 \mathrm{D}$ viscous flow model. Tectonophysics 465, 128-135.

Zhou P., Mukasa S., 1997. Nd-Sr-Pb isotopic, and major- and trace-element geochemistry of Cenozoic lavas from the Khorat Plateau, Thailand, sources and petrogenesis. Chemical Geology 137, 175-193. 